\title{
Total Synthesis of Zephycarinatines via Photocatalytic Reductive Radical ipso - Cyclization
}

\section{AUTHOR(S):}

Takeuchi, Haruka; Inuki, Shinsuke; Nakagawa, Kohei; Kawabe, Takaaki; Ichimura, Atsuhiko; Oishi, Shinya; Ohno, Hiroaki

\section{CITATION:}

Takeuchi, Haruka ... [et al]. Total Synthesis of Zephycarinatines via Photocatalytic Reductive Radical ipso - Cyclization. Angewandte Chemie 2020, 59(47): 21210-21215

\section{ISSUE DATE:}

2020-11-16

URL:

http://hdl.handle.net/2433/259186

\section{RIGHT:}

This is the peer reviewed version of the following article: ['Angewandte Chemie - International Edition', 59(47), 2121021215], which has been published in final form at https://doi.org/10.1002/anie.202009399. This article may be used for non-commercial purposes in accordance with Wiley Terms and Conditions for Use of Self-Archived Versions.; The fulltext file will be made open to the public on 11 September 2021 in accordance with publisher's 'Terms and Conditions for Self-Archiving'.; この論文は出版社版でありません。引用の際には出版社版をご確認ご利用ください。；This is not the published version. Please cite only the published version. 


\title{
Total Synthesis of Zephycarinatines via Photocatalytic Reductive Radical ipso-Cyclization
}

\author{
Haruka Takeuchi, Shinsuke Inuki, ${ }^{*}$ Kohei Nakagawa, Takaaki Kawabe, Atsuhiko Ichimura, Shinya \\ Oishi, and Hiroaki Ohno*
}

\begin{abstract}
We report herein a nonbiomimetic strategy for the total synthesis of the plicamine-type alkaloids, zephycarinatines C and D. The key feature of the synthesis was the stereoselective reductive radical ipso-cyclization using visible-light-mediated photoredox catalysis. This cyclization enabled the construction of a 6,6 -spirocyclic core structure by the addition of the carbon-centered radical onto the aromatic ring. The biological evaluation of zephycarinatines and their derivatives revealed that the synthetic derivative having a keto group displayed moderate inhibitory activity against LPS-induced NO production. This approach would offer future opportunities to expand the chemical diversity derived from plicamine-type alkaloids as well as provide useful intermediates for their syntheses.
\end{abstract}

\section{Introduction}

Amaryllidaceae alkaloids are structurally diverse natural products possessing various biological activities. ${ }^{[1]}$ Zephycarinatines (1) were isolated from Zephyranthes carinata Herbert (Amaryllidaceae) by Yao et al. in 2017 (Scheme 1).[2] Their structure is classified as a plicamine-type alkaloid that has a 6,6-spirocyclic core structure with multiple stereogenic centers. As a structural analog, zephygranditines including zephygranditine A (2) have been reported (Scheme 1). Some of the plicamine-type alkaloids and their derivatives show important biological activities. For example, zephygranditines exhibit cytotoxic properties against a variety of cancer cell lines, and antiinflammatory activities according to the inhibitory effects on LPSinduced NO production. ${ }^{[3]}$ In contrast, the detailed biological activities of zephycarinatines (1) have not been reported.

Owing to their biological importance and structural appeal, these alkaloids have been the target of many synthetic studies. ${ }^{[1 a}$, 1c] Whereas the total syntheses of zephycarinatines (1) have not been accomplished, some groups have reported the total synthesis of plicamine (3), ${ }^{[4]}$ which has a $p$-hydroxyphenethyl group on the nitrogen atom in the B-ring and a methoxy group on the $\mathrm{C}$-ring with the opposite configuration to the zephycarinatines. One of the keys to the synthesis of zephycarinatines is the construction of a quaternary carbon in the center of the core scaffold. In the reported total synthesis of plicamine (3), its quaternary carbon center was formed by an intramolecular oxidative coupling reaction between electron-rich aromatic rings

[^] H. Takeuchi, Prof. Dr. S. Inuki, K. Nakagawa, T, Kawabe, Dr. A Ichimura, Prof. Dr. S. Oishi, Prof. Dr. H. Ohno Graduate School of Pharmaceutical Sciences Kyoto University

Sakyo-ku, Kyoto 606-8501 (Japan)

E-mail: sinuki@pharm.kyoto-u.ac.jp, hohno@pharm.kyoto-u.ac.jp

Supporting information and the ORCID identification number(s) for the author(s) of this article can be found under:

(Scheme 1, route a), ${ }^{[4]}$ which is similar to how it is formed from knowledge of its biosynthetic pathway. ${ }^{[1]}$ As part of an ongoing program toward the synthesis of biologically active alkaloids, ${ }^{[5]}$ we designed a nonbiomimetic synthetic strategy for zephycarinatines $C$ (1a) and D (1b) through the creation of a quaternary carbon via a different manner from the biosynthesis (nonbiomimetic route; route $b$ ) ${ }^{[6]}$ which would possibly expand their analog diversity. To achieve this purpose, we planned a photocatalytic reductive radical ipso-cyclization onto the aromatic rings as the key reaction, enabling direct access to the 6,6-spirocyclic core structure of the zephycarinatines (1)

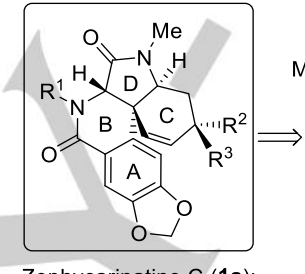

Zephycarinatine $\mathrm{C}(\mathbf{1 a})$ :

$\mathrm{R}^{1}=$ isopentyl, $\mathrm{R}^{2}=\mathrm{OMe}, \mathrm{R}^{3}=\mathrm{H}$ Zephycarinatine $\mathrm{D}(\mathbf{1} \mathbf{b})$ :

$\mathrm{R}^{1}=\mathrm{Me}, \mathrm{R}^{2}=\mathrm{OMe}, \mathrm{R}^{3}=\mathrm{H}$

Zephygranditine A (2)

$\mathrm{R}^{1}=(S)$-s-pentyl, $\mathrm{R}^{2}=\mathrm{OMe}, \mathrm{R}^{3}=\mathrm{H}$

Plicamine (3):

$\mathrm{R}^{1}=p$-hydroxyphenethyl, $\mathrm{R}^{2}=\mathrm{H}, \mathrm{R}^{3}=\mathrm{OMe}$

Scheme 1. Structures of Zephycarinatine, Zephygranditine and Plicamine, and Strategy for the Synthesis of Zephycarinatines

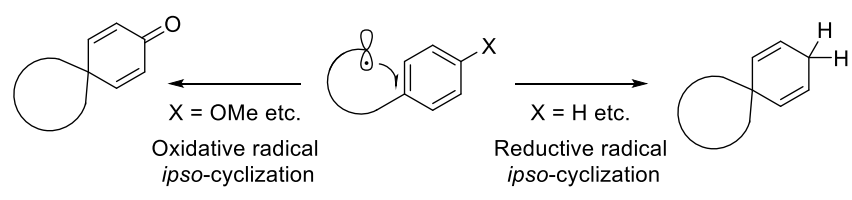

Scheme 2. Oxidative and Reductive Radical ipso-Cyclization

The radical ipso-cyclization, classfied as either an oxidative or a reductive type, has emerged as an attractive tool for the synthesis of spirocycles (Scheme 2). ${ }^{[7]}$ Various useful methods have been reported for the oxidative cyclization, ${ }^{[7]}$ which is represented by Curran's work involving the cyclization of an aryl radical at the ipso-position of a $p$-O-aryl-substituted benzamide..$^{[8]}$ By comparison, research into reductive radical ipso-cyclization is relatively limited..$^{[9]}$ Our group developed a samarium(II)-mediated reductive ipso-cyclization via an intramolecular ketyl radical addition onto aromatic rings. ${ }^{[9 \mathrm{~d}, 9 \mathrm{e}]}$ During the course of this study, Yoshimi et al. reported an intramolecular ipso-cyclization through photoinduced electron transfer-promoted decarboxylation of amino acid derivatives bearing an $\mathrm{N}$-(2-phenyl)benzoyl group. ${ }^{\text {[9h] }}$ More recently, Jui developed a photocatalytic dearomative 

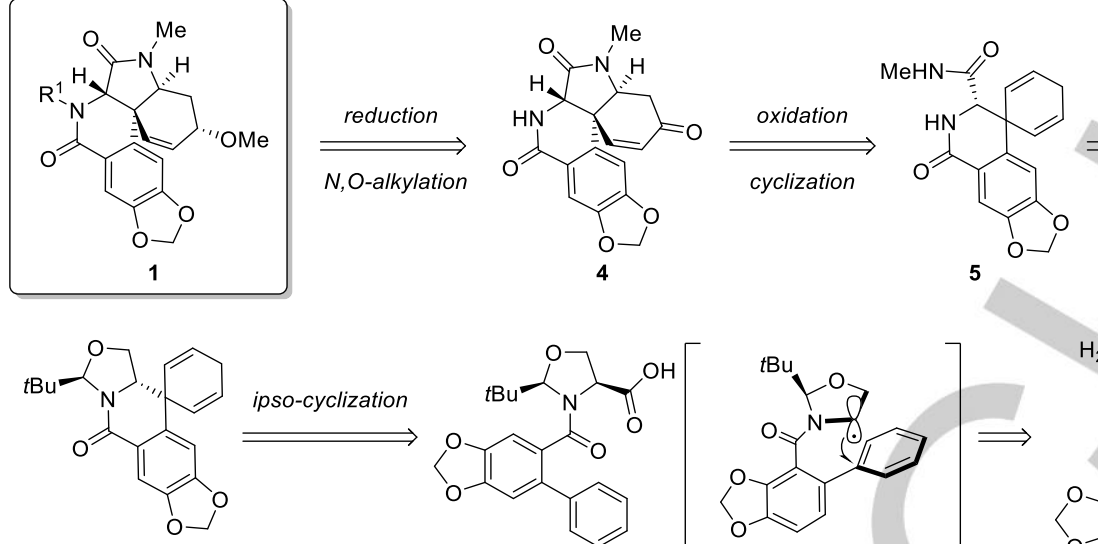

6
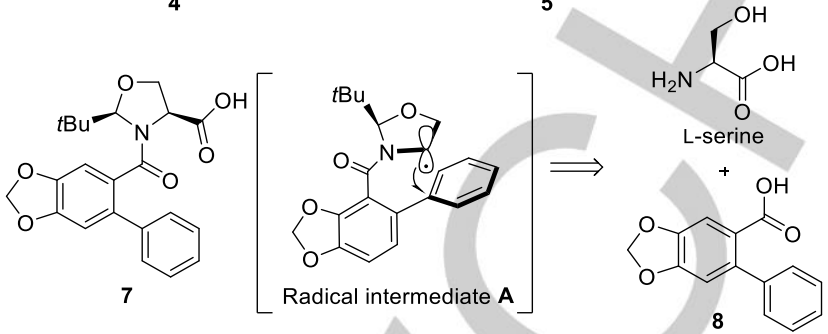

Scheme 3. Retrosynthetic Analysis of Zephycarinatines

hydroarylation triggered by an aryl halide reduction. ${ }^{[9]]}$ However, despite their utility, their application to total synthesis still remains a challenge, presumably because of the difficulty in carrying out stereoselective ipso-cyclization using substrates congested with functional groups.

We focused on visible-light-mediated decarboxylation of amino acid derivatives for stereoselective ipso-cyclization. The initial carbon radical generation required for cyclization can be conducted under mild conditions, only irradiation with an LED lamp. ${ }^{[10]}$ This approach should facilitate the synthesis of plicamine-type alkaloids and their analogs featuring substantial structural and/or electronic variation, because the key radical cyclization would likely not be limited only to those requiring highly electron-rich and p-nucleophilic species. In this paper, the total synthesis of zephycarinatines $C$ and $D$ via nonbiomimetic visiblelight-mediated ipso-cyclization is described. Evaluation of their inhibitory activity against NO production is also presented.

\section{Results and Discussion}

The retrosynthetic strategy for achieving zephycarinatines (1) is illustrated in Scheme 3. We planned to introduce the $\mathrm{R}^{1}$ group (nitrogen substituent) at the last stage of the synthetic route to allow synthesis of a variety of analogs having substituents on the amide nitrogen. We posited that the methoxy group would be derived from the carbonyl group of $\mathbf{4}$. The precursor 4 was envisaged to result from the oxidation of the 1,4-diene and subsequent 1,4-addition reaction of the amide $\mathbf{5}$. The amide 5 could be obtained by functionalization of the hemiaminal $\mathbf{6}$, including aminal deprotection, oxidation, and amide formation with methylamine. We expected that the hemiaminal 6 could be constructed through the visible-light-mediated radical ipsocyclization of carboxylic acid 7 . This disconnection represented the major synthetic challenge in this synthetic route, requiring a stereoselective ipso-cyclization of the $\alpha$-amino carbon radical intermediate $\mathbf{A}$ generated by the $\mathrm{CO}_{2}$-extrusion of the carboxyl radical. For this purpose, we designed the oxazolidine substrate 7 having the potential to control the chiral center at the $\alpha$-position, referring to the self-regeneration of stereocenters (SRS) principle developed by Seebach et al. ${ }^{[11]}$ The substrate 7 would be prepared from L-serine and biphenyl carboxylic acid $\mathbf{8}$ as starting materials.
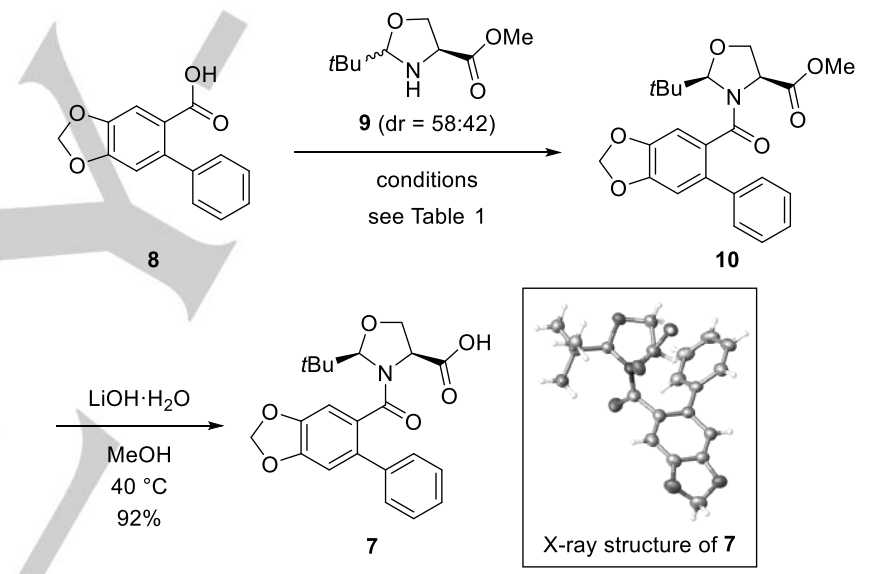

Scheme 4. Synthesis of the Key Precursor 7.

Table 1. Investigation of the Coupling Reaction between $\mathbf{8}$ and $\mathbf{9}$

\begin{tabular}{|c|c|c|c|}
\hline Entry & Condition & $\begin{array}{l}\text { Yield of } 10 \\
(\%)^{[a][b]}\end{array}$ & $\mathrm{dr}^{[\mathrm{c}]}$ \\
\hline 1 & 8, 9, EDC, $\mathrm{HOBt}, \mathrm{CH}_{2} \mathrm{Cl}_{2}$, rt & ND & \\
\hline 2 & $\begin{array}{l}\text { 8, } \mathrm{SOCl}_{2}, \mathrm{DMF}, \mathrm{CH}_{2} \mathrm{Cl}_{2} \text { then } \mathbf{9}, \mathrm{NaHCO}_{3} \text {, } \\
\mathrm{THF} / \mathrm{H}_{2} \mathrm{O}, 60^{\circ} \mathrm{C}\end{array}$ & ND & \\
\hline 3 & 8, $\mathrm{Et}_{3} \mathrm{~N}, \mathrm{MsCl}, \mathrm{CH}_{2} \mathrm{Cl}_{2}$ then $9,0{ }^{\circ} \mathrm{C}$ to rt & 22 & \\
\hline 4 & 8, 9, $\mathrm{Et}_{3} \mathrm{~N}, \mathrm{CH}_{2} \mathrm{Cl}_{2}$ then $\mathrm{MsCl}, 0^{\circ} \mathrm{C}$ to rt & 66 & $>99: 1$ \\
\hline 5 & 8, 9, $\mathrm{Et}_{3} \mathrm{~N}, \mathrm{CH}_{2} \mathrm{Cl}_{2}$ then $\mathrm{Ms}_{2} \mathrm{O}, 0^{\circ} \mathrm{C}$ to rt & 46 & $>99: 1$ \\
\hline 6 & 8, 9, $\mathrm{Et}_{3} \mathrm{~N}, \mathrm{CH}_{2} \mathrm{Cl}_{2}$ then $\mathrm{BuOCOCl}, 0^{\circ} \mathrm{C}$ to $\mathrm{rt}$ & ND & \\
\hline
\end{tabular}

[a] Isolated yields. [b] ND = not detected. [c] Determined by ${ }^{1} \mathrm{H}$ NMR analysis.

Our preparation of the key precursor 7 for the radical ipsocyclization reaction is shown in Scheme 4 and Table 1. Initially, we investigated the coupling reaction between the known oxazolidine 9 $^{[12]}$ derived from L-serine and the biphenyl-2carboxylic acid derivative $8 .{ }^{[13]}$ The reaction using conventional 
coupling reagents for the amide bond formation, such as EDC, did not produce the amide 10 (Table 1, entry 1). When the corresponding acid chloride prepared from 8 was used, the desired product was not observed (entry 2). Macherla et al. reported the $\mathrm{MsCl}$-mediated coupling reaction of the oxazolidine 9 with an aliphatic carboxylic acid derivative. ${ }^{[14]}$ Following the literature procedure, the oxazolidine $\mathbf{9}$ was added to the reaction mixture of the carboxylic acid $\mathbf{8}$ and $\mathrm{MsCl}$ to provide the desired product $\mathbf{1 0}$ in low yield (22\%, entry 3$)$. After further examination, we found that the addition of $\mathrm{MsCl}$ to the mixture of substrates $\mathbf{8}$, 9, and $\mathrm{Et}_{3} \mathrm{~N}$ afforded the oxazolidine $\mathbf{1 0}$ in $66 \%$ yield as a single diastereomer (entry 4). The preferential production of cis-10 could be rationalized by the selective acylation of the cis-oxazolidine $\mathbf{9}$, resulting from the steric difference between the equiblated cisand trans-isomers of 9 via a ring-opened intermediate. ${ }^{[15]}$ The reaction under these conditions proceeded with sufficient reproducibility at a multi-gram scale. Changing $\mathrm{MsCl}$ to $\mathrm{Ms}_{2} \mathrm{O}$ or $\mathrm{BuOCOCl}$ was not effective (entries 5 and 6). Subsequently, treatment of the ester $\mathbf{1 0}$ with $\mathrm{LiOH} \cdot \mathrm{H}_{2} \mathrm{O}$ furnished the key carboxylic acid 7 (Scheme 4). The relative configuration of $7^{[16]}$ was confirmed by X-ray crystallography.

Table 2. Investigation of the Reductive Radical ipso-Cyclization of 7

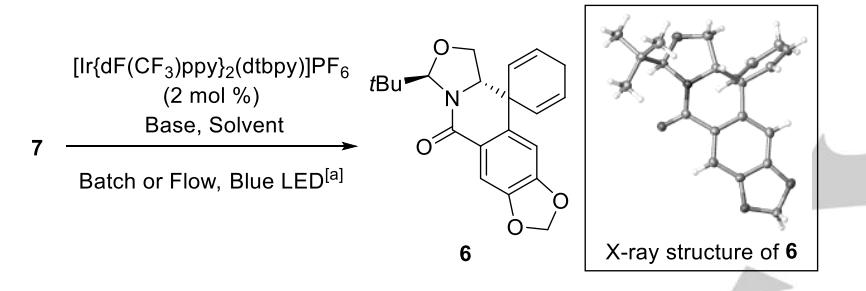

\begin{tabular}{|c|c|c|c|c|c|}
\hline Entry & Process & Base & Solvent & Time $(h)^{[b]}$ & Yield $(\%)^{[c][d]}$ \\
\hline 1 & Batch & $\mathrm{K}_{2} \mathrm{CO}_{3}$ & DMF & 24 & trace \\
\hline 2 & Batch & $\mathrm{K}_{2} \mathrm{CO}_{3}$ & THF & 24 & ND \\
\hline 3 & Batch & $\mathrm{K}_{2} \mathrm{CO}_{3}$ & $\mathrm{CH}_{2} \mathrm{Cl}_{2}$ & 24 & ND \\
\hline 4 & Batch & $\mathrm{K}_{2} \mathrm{CO}_{3}$ & $\mathrm{MeCN}$ & 24 & 32 \\
\hline 5 & Batch & $\mathrm{Cs}_{2} \mathrm{CO}_{3}$ & $\mathrm{MeCN}$ & 24 & 26 \\
\hline 6 & Batch & $\mathrm{Na}_{2} \mathrm{CO}_{3}$ & $\mathrm{MeCN}$ & 24 & trace \\
\hline $7^{[\mathrm{e}]}$ & Batch & $\mathrm{K}_{2} \mathrm{CO}_{3}$ & $\mathrm{MeCN}$ & 24 & 58 \\
\hline $8^{[e]}$ & Batch & $\mathrm{K}_{2} \mathrm{CO}_{3}$ & $\mathrm{MeCN} / \mathrm{H}_{2} \mathrm{O}(10 / 1)$ & 24 & 31 \\
\hline $9^{[e]}$ & Batch & TMG & $\mathrm{MeCN}$ & 24 & 31 \\
\hline 10 & Flow & $\mathrm{K}_{2} \mathrm{CO}_{3}$ & $\mathrm{MeCN} / \mathrm{H}_{2} \mathrm{O}(10 / 1)$ & 2 & 22 \\
\hline 11 & Flow & TMG & $\mathrm{MeCN}$ & 2 & 40 \\
\hline 12 & Flow & TMG & $\mathrm{MeCN}$ & 4 & 48 \\
\hline
\end{tabular}

[a] The reaction was carried out with irradiation from a $40 \mathrm{~W}$ blue LED light using an EvoluChem ${ }^{\mathrm{TM}}$ PhotoRedOx Box. [b] In the cases of a flow reaction, the residence time is shown. [c] Isolated yields. [d] ND = not detected. [e] $40 \mathrm{~W}$ blue LED $(\times 2)$ were used instead of an EvoluChem ${ }^{\mathrm{TM}} \cdot \mathrm{dF}\left(\mathrm{CF}_{3}\right) \mathrm{ppy}=2-(2,4-$ difluorophenyl)-5-(trifluoromethyl)pyridine; dtbpy $=4,4$ '-di-tert-butyl-2,2' bipyridine. $\mathrm{TMG}=1,1,3,3$-tetramethylguanidine

Next, we examined the key radical ipso-cyclization reaction (Table 2). Reactions were carried out under irradiation with a 40
W LED bulb using an EvoluChem ${ }^{\mathrm{TM}}$ PhotoRedOx Box (Figure S1). Treatment of 7 with $\mathrm{K}_{2} \mathrm{CO}_{3}$ and $\left[\operatorname{Ir}\left\{\mathrm{dF}\left(\mathrm{CF}_{3}\right) \text { ppy }\right\}_{2}(\mathrm{dtbpy})\right] \mathrm{PF}_{6}$ as a photoredox catalyst in DMF under irradiation with visible-light (the known condition for generating a radical intermediate from a carboxylic acid) ${ }^{[10 c]}$ gave a trace amount of the desired product 6 (entry 1). Changing the solvent from DMF to THF or $\mathrm{CH}_{2} \mathrm{Cl}_{2}$ did not enhance the yield of 6 (entries 2 and 3 ). When MeCN was used as the reaction solvent, the desired spiro-compound 6 was obtained in $32 \%$ yield as a single diastereomer (entry 4 ). The relative configuration of $6^{[16]}$ was determined by $\mathrm{X}$-ray crystallography, indicating that the ipso-cyclization occurred from the sterically less hindered face opposite to the $t \mathrm{Bu}$ group as expected. The use of $\mathrm{Cs}_{2} \mathrm{CO}_{3}$ or $\mathrm{Na}_{2} \mathrm{CO}_{3}$ decreased the yield of 6 (entries 5 and 6). Further optimization revealed that when the reaction was carried out using two $40 \mathrm{~W}$ LED bulbs directly irradiating the reaction vessel (Figure S2), the desired product 6 was afforded in $58 \%$ yield (entry 7 ). The reaction was amenable to operation on $300 \mathrm{mg}$ scale to furnish the spiro-compound 6 in $40 \%$ isolated yield. We next focused on optimizing the reaction using a continuous flow reactor that allowed for efficient conversion, mainly by improving the irradiation efficiency of the reaction mixture compared with batch processing (Figure S3). ${ }^{[17]}$ The optimized condition (entry 7) was not suitable for use in flow reactors because the inorganic base was not completely soluble in MeCN. Thus, we examined conditions that provide a homogeneous reaction mixture. When a mixed solvent of $\mathrm{MeCN} / \mathrm{H}_{2} \mathrm{O}(10: 1)$ was used, a clear reaction mixture was formed but the yields of 6 decreased to $31 \%$ (entry 8). Using a soluble base such as TMG instead of $\mathrm{K}_{2} \mathrm{CO}_{3}$ provided the desired product 6 in $31 \%$ yield. These homogeneous conditions were applied to continuous flow chemistry (Figure S3). The flow reactions with a $2 \mathrm{~h}$ residence time provided 6 in low to moderate yields (entries 10 and 11), while increasing the residence time to $4 \mathrm{~h}$ enhanced the yield to $48 \%$ (entry 12). These results would contribute to the development of further scale-up synthesis.

With the core spiro-scaffold in hand, we turned our attention to the construction of the D-ring of zephycarinatine (Scheme 5). The hemiaminal 6 was converted to the corresponding alcohol in the presence of $\mathrm{TsOH}$. The oxidation of the alcohol with AZADOL $^{[18]}$ gave the carboxylic acid, which was treated with methylamine and EDC to afford the $N$-methyl amide 5 in $64 \%$ yield in two steps. Our investigation into the oxidation of the 1,4-diene is summarized in Table 3 . Referring to previous reports, we attempted the oxidation using several oxidants such as tBuOOH/PDC, ${ }^{[19]} \mathrm{MnO}_{2}{ }^{[20]}$ and $\mathrm{DDQ},{ }^{[21]}$ which did not afford the desired product (entries 1-3). On the other hand, the oxidation with catalytic tetrapropylammonium perruthenate (TPAP) ${ }^{[22]}$ provided the desired cyclic product 4 as a sole diastereomer through the oxidation of 1,4-diene followed by intramolecular 1,4addition of the $\mathrm{N}$-methyl amide (entry 4). When the reaction was carried out at room temperature, the imine was observed as the overoxidation side product. Several investigations revealed that the desired product $\mathbf{4}$ was produced in $70 \%$ yield by careful control of the reaction temperature (entry 5). After confirming the completion of the oxidation of the 1,4 -diene at $-20^{\circ} \mathrm{C}$, the reaction temperature was increased to $0{ }^{\circ} \mathrm{C}$ to furnish the 1,4 -addition to the $\alpha, \beta$-unsaturated ketone under a near-neutral condition. The relative configuration of $4^{[16]}$ was determined by $X$-ray crystallography. In Ley's synthesis of plicamine, ${ }^{[4 a, 4 b]}$ the D-ring formation was accomplished via a stereoselective 1,4-addition under an acidic condition. In contrast, Miranda et al. reported that 
a base-mediated 1,4-addition of various related substrates proceeded with relatively low diastereoselectivity. ${ }^{[4]}$ These findings implied that the selectivity for D-ring formation through 1,4-addition could depend mainly on the reaction condition, rather than the substrate structure.<smiles>CC(C)[C@@H]1OCC2N1C(=O)c1cc3c(cc1C21C=CCC=C1)OCO3</smiles>
6
1) $\mathrm{TsOH} \cdot \mathrm{H}_{2} \mathrm{O}, \mathrm{MeCN} / \mathrm{H}_{2} \mathrm{O}$ $90{ }^{\circ} \mathrm{C}, 77 \%$

2) AZADOL, $\mathrm{NaClO}_{2}, \mathrm{NaOC}$ $\mathrm{MeCN} / \mathrm{pH} 7$ buffer $0{ }^{\circ} \mathrm{C}$ to $\mathrm{rt}$

3) $\mathrm{MeNH}_{2}, \mathrm{EDC}, \mathrm{HOBt}$ DIPEA, DMF, $0{ }^{\circ} \mathrm{C}$ to $\mathrm{rt}$ $64 \%$ (2 steps)

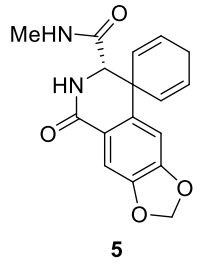

to the mesylate prepared from the corresponding alcohol and $\mathrm{MsCl}{ }^{[24]}$ Thus, we conducted the reaction of the alcohol 11 with $\mathrm{MsCl}$ and $\mathrm{Et}_{3} \mathrm{~N}$. Unfortunately, the undesired chloride was obtained without producing the corresponding mesylate, probably because of the substitution of chloride derived from $\mathrm{MsCl}$. Instead, mesylation of 11 with $\mathrm{Ms}_{2} \mathrm{O}$ followed by treatment with $\mathrm{MeOH}$ was investigated, resulting in successful incorporation of the methoxy group with stereoinversion. Without purification, the subsequent $\mathrm{N}$-alkylation with isopentyl bromide and $\mathrm{NaH}$ completed the total synthesis of zephycarinatine $\mathrm{C}(\mathbf{1 a})$ in $23 \%$ in three steps from $\mathbf{1 1}$ with recovery of the precursor 13 in $21 \%$ (29\% brsm). By changing the electrophile to Mel, the total synthesis of zephycarinatine D (1b) was accomplished in $52 \%$ in three steps with a small amount of removable diene 14. All the spectroscopic data were in agreement with those of the natural zephycarinatines $C$ and $D$ reported in the literature ${ }^{[2]}$ zzephycarinatine $\mathrm{C}:[\alpha]^{26} \mathrm{D}+141(c$ $0.060, \mathrm{MeOH})$; lit. $[\alpha]_{D}+108(\mathrm{c} 0.14, \mathrm{MeOH})$, zephycarinatine $\mathrm{D}$ : $[\alpha]^{26} \mathrm{D}+172(c 0.15, \mathrm{MeOH})$; lit. $\left.[\alpha]_{\mathrm{D}}+176(\mathrm{c} 0.1, \mathrm{MeOH})\right\}$.

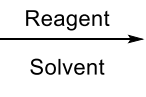

see Table 3<smiles>CN1OCOc2cc3c4cc2C=CC(=O)C[C@@H]3[C@@H](NC4=O)C1=O</smiles>

4

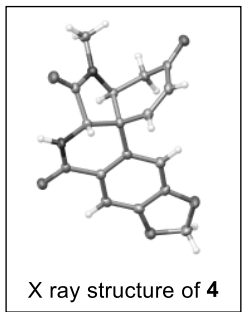

Scheme 5. Synthesis of the Ketone 4

Table 3. Optimization of the Oxidation of 1,4-Diene 5

\begin{tabular}{ccccc}
\hline Entry & Reagent & Solvent & Temp. $\left({ }^{\circ} \mathrm{C}\right)$ & Yield (\%) ${ }^{[\mathrm{a}] \mathrm{b}]}$ \\
\hline 1 & tBuOOH, PDC & $\mathrm{DMF}$ & $\mathrm{rt}$ & $\mathrm{ND}$ \\
2 & $\mathrm{MnO}_{2}$ & $\mathrm{CH}_{2} \mathrm{Cl}_{2}$ & $\mathrm{rt}$ & $\mathrm{ND}$ \\
3 & $\mathrm{DDQ}$ & $\mathrm{THF}$ & 0 to rt & $\mathrm{ND}$ \\
4 & $\mathrm{NMO}$, TPAP & $\mathrm{MeCN}$ & $\mathrm{rt}$ & 50 \\
5 & $\mathrm{NMO}$, TPAP & $\mathrm{MeCN}$ & -20 to 0 & 70 \\
\hline
\end{tabular}

[a] Isolated yield. [b] ND = not detected.

We next focused on the total syntheses of zephycarinatines $C$ and D (Scheme 6). The synthesis commenced with the conversion of the carbonyl group to the methoxy group. Although initial attempts to reduce the carbonyl group by employing $\mathrm{NaBH}_{4} / \mathrm{CeCl}_{3}$ or DIBAL-H failed, treatment of 4 with $\mathrm{LiAlH}_{4}$ allowed the 1,2-reduction of the carbonyl group to provide the alcohol 11 in $78 \%$ yield as a single diastereomer. Without determining the relative configuration, the alcohol 11 was converted into the corresponding $\mathrm{N}, \mathrm{O}$-dimethylated product 12 by treatment of $\mathrm{NaH}$ and $\mathrm{Mel}$ in DMF. Unfortunately, the NMR spectral data of $\mathbf{1 2}$ did not agree with those of natural zephycarinatine D. NOESY correlation revealed that 12 possessed the $\mathrm{H}_{3} / \mathrm{H}_{4 a}$-syn relative stereochemistry. ${ }^{[23]}$ Additionally, the observed $\mathrm{H}_{3}-\mathrm{H}_{4 \alpha}(J=10.3 \mathrm{~Hz})$ and $\mathrm{H}_{4 \mathrm{a}}-\mathrm{H}_{4 \alpha}(J=12.6 \mathrm{~Hz})$ coupling constants established the pseudo-axial orientation of $\mathrm{H}_{3}$ and $\mathrm{H}_{4 a}$. These observations indicated that the $\mathrm{LiAlH}_{4}$-reduction proceeded from the side of the benzene ring of $\mathbf{4}$ to give the precursor 11 of epi-zephycarinatine D (12). We next attempted to introduce the methoxy group to the C3 position via stereoinversion. Ley et al. reported that in the total synthesis of obliquine (a plicamine analog), the introduction of the methoxy group was accomplished through the nucleophilic attack of $\mathrm{MeOH}$

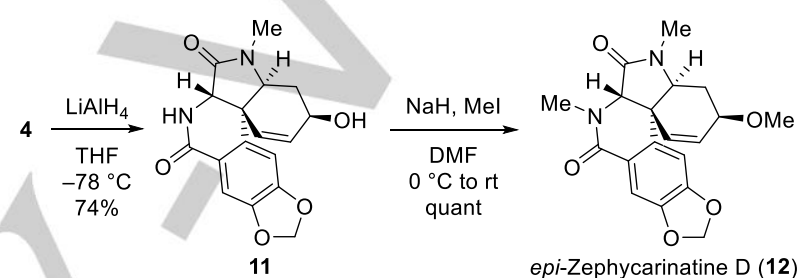

epi-Zephycarinatine $\mathrm{D}(\mathbf{1 2})$

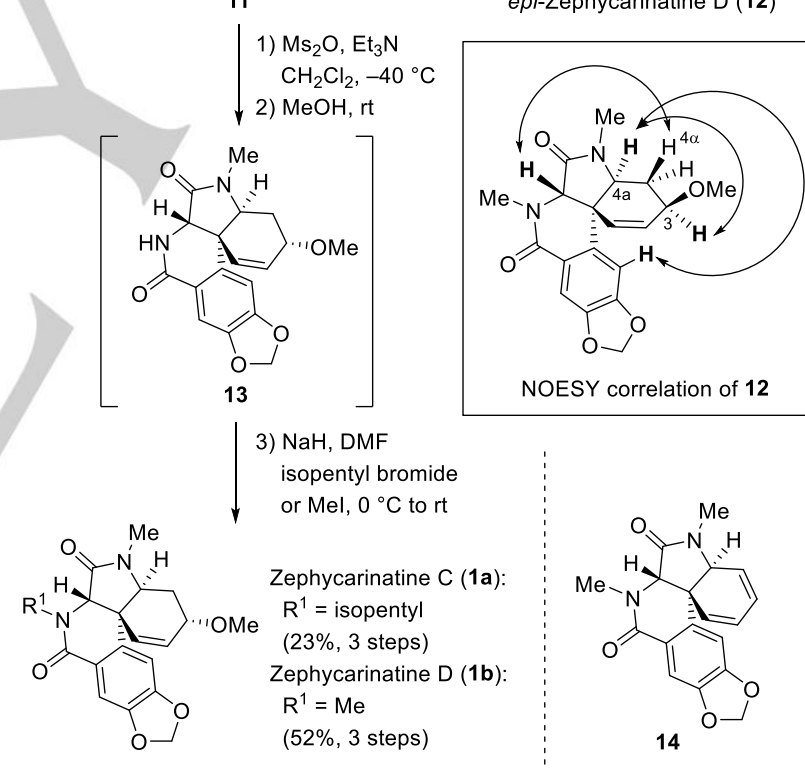

Scheme 6. Total Synthesis of Zephycarinatines (1)

Scheme 7. Synthesis of Zephycarinatine Derivative 17

With a facile method to synthesize the natural zephycarinatines in hand, we synthesized a derivative with a nonsubstituted A ring (Scheme 7 and S2). The zephycarinatine D

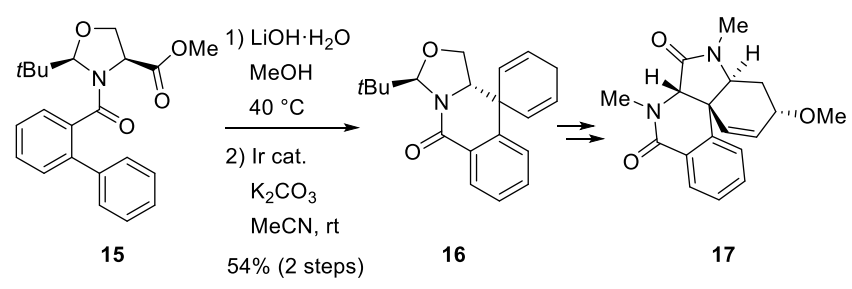


WILEY-VCH

analog 17 lacking a methylenedioxy group was obtained in a similar manner. As expected, the key radical ipso-cyclization of the substrate without an electron donating group proceeded smoothly to provide the desired cyclization product 16 in 54\% yield in two steps.

Finally, we evaluated the inhibitory activities of zephycarinatines $\mathrm{C}, \mathrm{D}$, and their synthetic derivatives on NO production by LPS-stimulated RAW264.7 cells (Figure 1). ${ }^{[3]}$ Although the natural zephycarinatines $C(\mathbf{1 a})$ and $D(\mathbf{1 b})$ as well as their derivative $\mathbf{1 7}$ did not show significant inhibitory activities at $30 \mu \mathrm{M}$, the keto derivative $\mathbf{4}$ at $30 \mu \mathrm{M}$ displayed a comparable level of activity to indomethacin at $100 \mu \mathrm{M}$ (positive control). The derivative $\mathbf{4}$ exhibited dose-dependent inhibition of NO production $\left(\mathrm{IC}_{50}=65.3 \mu \mathrm{M}\right.$, Figure 1b). No cytotoxicity was observed in the concentration range of $0.3-300 \mu \mathrm{M}$ of 4 (data not shown).
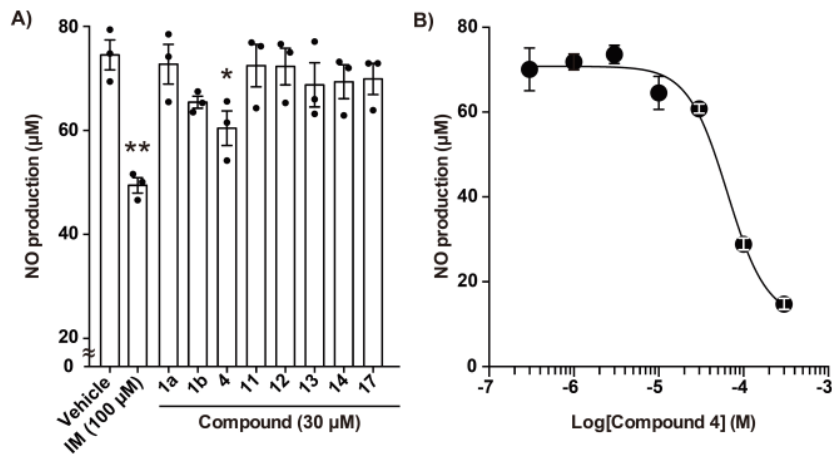

Figure 1. Inhibitory activity of eight compounds on NO production by LPS stimulated RAW264.7 cells. A) Inhibitory activities of each compound. B) Dosedependent inhibition of compound 4 on NO production by LPS-stimulated RAW264.7 cells. The data represent the mean \pm SEM $(n=3$ in each treatment, ${ }^{* *} p<0.01,{ }^{*} p<0.05$ vs vehicle, one-way ANOVA and Dunnett's test). IM = indomethacin.

\section{Conclusion}

In conclusion, we accomplished the first total synthesis of zephycarinatines $\mathrm{C}$ and $\mathrm{D}$ starting from the known carboxylic acid $8(2.1 \%$ and $4.7 \%$ overall yields, respectively, 11 steps). The synthesis highlights a nonbiomimetic strategy for the stereoselective construction of the B-ring based on photocatalytic reductive radical ipso-cyclization. The TPAP oxidation of 1,4diene followed by intramolecular 1,4-addition allowed the construction of D-ring. We found that the keto derivative demonstrated moderate inhibitory activity against LPS-induced NO production. This strategy would contribute to expanding the chemical space of plicamine-type alkaloids that is normally inaccessible using biomimetic approaches.

\section{Acknowledgments}

This work was supported by the JSPS KAKENHI (Grant Numbers JP2OK06938, 20H04773 and 17H03971), and AMED under Grant Number JP19gm1010007.

\section{Conflict of interest}

The authors declare no conflict of interest.
Keywords: alkaloid $\cdot$ natural products $\cdot$ photocatalyst $\cdot$ radical ipso-cyclization $\cdot$ total synthesis

[1] a) Z. Jin, Nat. Prod. Rep. 2009, 26, 363-381; b) M. B. Kilgore, T. M. Kutchan, Phytochem. Rev. 2016, 15, 317-337; c) Z. Jin, G. Yao, Nat. Prod. Rep. 2019, 36, 1462-1488.

[2] G. Zhan, J. Zhou, J. Liu, J. Huang, H. Zhang, R. Liu, G. Yao, J. Nat. Prod. 2017, 80, 2462-2471.

[3] H. Y. Wang, S. M. Qu, Y. Wang, H. T. Wang, Fitoterapia 2018, 130, 163168.

[4] a) I. R. Baxendale, S. V. Ley, C. Piutti, Angew. Chem. 2002, 114, 22982301; Angew. Chem. Int. Ed. 2002, 41, 2194-2197; b) I. R. Baxendale S. V. Ley, M. Nessi, C. Piutti, Tetrahedron 2002, 58, 6285-6304; c) M. V. Mijangos, L. D. Miranda, Org. Biomol. Chem. 2016, 14, 3677-3680.

[5] a) S. Inuki, S. Oishi, N. Fujii, H. Ohno, Org. Lett. 2008, 10, 5239-5242; b) H. Chiba, S. Oishi, N. Fujii, H. Ohno, Angew. Chem. Int. Ed. 2012, 51 9169-9172; Angew. Chem. 2012, 124, 9303-9306; c) S. Naoe, Y Yoshida, S. Oishi, N. Fujii, H. Ohno, J. Org. Chem. 2016, 81, 5690-5698; d) J. Matsuoka, Y. Matsuda, Y. Kawada, S. Oishi, H. Ohno, Angew. Chem. Int. Ed. 2017, 56, 7444-7448; Angew. Chem. 2017, 129, 7552 7556

[6] E. R. Welin, A. Ngamnithiporn, M. Klatte, G. Lapointe, G. M. Pototschnig, M. S. J. McDermott, D. Conklin, C. D. Gilmore, P. M. Tadross, C. K. Haley, K. Negoro, E. Glibstrup, C. U. Grunanger, K. M. Allan, S. C. Virgil, D. J. Slamon, B. M. Stoltz, Science 2019, 363, 270-275.

[7] For review, see: C. R. Reddy, S. K. Prajapti, K. Warudikar, R. Ranjan, B. B. Rao, Org. Biomol. Chem. 2017, 15, 3130-3151.

[8] F. G. L. de Turiso, D. P. Curran, Org. Lett. 2005, 7, 151-154.

[9] a) A. Citterio, R. Sebastiano, A. Maronati, R. Santi, F. Bergamini, J. Chem. Soc. Chem. Commun. 1994, 1517-1518; b) J. Boivin, M. Yousfi, S. Z. Zard, Tetrahedron Lett. 1997, 38, 5985-5988; c) D. Crich, J. T. Hwang, J. Org. Chem. 1998, 63, 2765-2770; d) H. Ohno, S. Maeda, M. Okumura, R. Wakayama, T. Tanaka, Chem. Commun. 2002, 316-317; e) H. Ohno, M. Okumura, S. Maeda, H. Iwasaki, R. Wakayama, T. Tanaka, J. Org. Chem. 2003, 68, 7722-7732; f) H. Iwasaki, T. Eguchi, N. Tsutsui, H. Ohno, T. Tanaka J. Org. Chem. 2008, 73, 7145-7152; g) G. Rousseau, F. Robert, Y. Landais, Chem. Eur. J. 2009, 15, 11160-11173; h) T. Yamada, Y. Ozaki, M. Yamawaki, Y. Sugiura, K. Nishino, T. Morita, Y. Yoshimi, Tetrahedron Lett. 2017, 58, 835-838; i) Q. Wang, Y. Qu, Q. Xia, H. Song, H. Song, Y. Liu, Q. Wang, Adv. Synth. Catal. 2018, 360, 2879-2884; j) A. R. Flynn, K. A. McDaniel, M. E. Hughes, D. B. Vogt, N. T. Jui, J. Am. Chem. Soc. 2020, 142, 9163-9168.

[10] For reviews, see: a) J. Xuan, Z. G. Zhang, W. J. Xiao, Angew. Chem. Int Ed. 2015, 54, 15632-15641; Angew. Chem. 2015, 127, 15854-15864; b) M. Rahman, A. Mukherjee, I. S. Kovalev, D. S. Kopchuk, G. V. Zyryanov, M. V. Tsurkan, A. Majee, B. C. Ranu, V. N. Charushin, O. N. Chupakhin S. Santra, Adv. Synth. Catal. 2019, 361, 2161-2214. For representative works, see: c) L. Chu, C. Ohta, Z. Zuo, D. W. MacMillan, J. Am. Chem. Soc. 2014, 136, 10886-10889; d) Q. Q. Zhou, W. Guo, W. Ding, X. Wu, X. Chen, L. Q. Lu, W. J. Xiao, Angew. Chem. Int. Ed. 2015, 54, 11196 11199; Angew. Chem. 2015, 127, 11196-11199; e) F. Le Vaillant, T. Courant, J. Waser, Angew. Chem. Int. Ed. 2015, 54, 11200-11204; Angew. Chem. 2015, 127, 11352-11356; For our recent works, see: f) S. Inuki, K. Sato, Y. Fujimoto, Tetrahedron Lett. 2015, 56, 5787-5790; g) S. Inuki, K. Sato, T. Fukuyama, I. Ryu, Y. Fujimoto, J. Org. Chem. 2017, 82, 1248-1253.

[11] D. Seebach, A. R. Sting, M. Hoffmann, Angew. Chem. Int. Ed. Engl. 1996, 35, 2708-2748; Angew. Chem. 1996, 108, 2881-2921.

[12] D. Seebach, J. D. Aebi, Tetrahedron Lett. 1984, 25, 2545-2548.

[13] H. A. Lloyd, K. S. Warren, H. M. Fales, J. Am. Chem. Soc. 1966, 88 5544-5549.

[14] T. T. Ling, V. R. Macherla, R. R. Manam, K. A. McArthur, B. C. M. Potts, Org. Lett. 2007, 9, 2289-2292.

[15] W. Ando, Y. Igarashi, L. Huang, Chem. Lett. 1987, 1361-1364.

[16] CCDC 2014792, 2014795, and 2014796 (4, 6, and 7, respectively) contain the supplementary crystallographic data for this paper. These data can be obtained free of charge from The Cambridge Crystallographic Data Centre. 


\section{RESEARCH ARTICLE}

[17] a) I. Ryu, T. Fukuyama, M. Rahman, M. Sato, Synlett 2008, 151-163; b) J. W. Tucker, Y. Zhang, T. F. Jamison, C. R. Stephenson, Angew. Chem. Int. Ed. 2012, 51, 4144-4147; Angew. Chem. 2012, 124, 4220-4223; c) D. Cambie, C. Bottecchia, N. J. Straathof, V. Hessel, T. Noel, Chem. Rev. 2016, 116, 10276-10341.

[18] Y. Iwabuchi, M. Shibuya, Y. Sasano, M. Tomizawa, T. Hamada, M. Kozawa, N. Nagahama, Synthesis 2011, 3418-3425.

[19] Z. H. Guo, A. G. Schultz, Tetrahedron Lett. 2004, 45, 919-921.

[20] P. M. Muller, R. Pfister, Helv. Chim. Acta 1983, 66, 771-779.

[21] R. Li, Z. Liu, L. Chen, J. Pan, K. Lin, W. Zhou, Beilstein J. Org. Chem. 2018, 14, 2340-2347.

[22] H. Fujishima, H. Takeshita, S. Suzuki, M. Toyota, M. Ihara, J. Chem. Soc. Perkin Trans. 1 1999, 2609-2616.

[23] The numbering of $\mathbf{1 2}$ follows the natural products (see Figure S4 in the Supporting information).

[24] I. R. Baxendale, S. V. Ley, Ind. Eng. Chem. Res. 2005, 44, 8588-8592. 


\section{Entry for the Table of Contents}
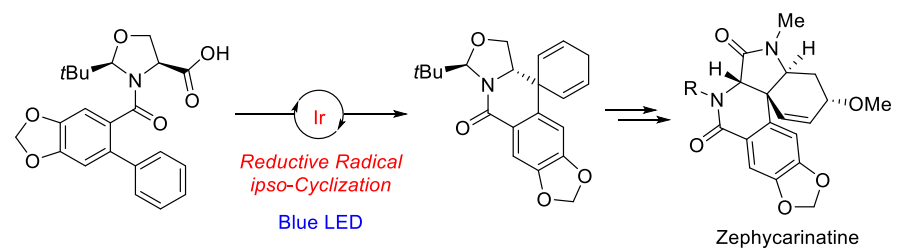

Total synthesis of the plicamine-type alkaloids, zephycarinatine $C$ and $D$, has been achieved. The key feature of the synthesis was the stereoselective radical ipso-cyclization using visible-light-mediated photoredox catalysis. The evaluation of zephycarinatines and their derivatives revealed that a synthetic derivative displayed moderate inhibitory activity against LPS-induced NO production. 